\title{
Quantifying importance and scaling effects of atmospheric deposition of inorganic fixed nitrogen for the eutrophic Black Sea
}

\author{
A. Varenik, S. Konovalov, and S. Stanichny \\ Marine Hydrophysical Institute, Kapitanskaya Street 2, Sevastopol \\ Correspondence to: S. Konovalov (sergey_konovalov@yahoo.com)
}

Received: 10 May 2015 - Published in Biogeosciences Discuss.: 16 July 2015

Revised: 28 September 2015 - Accepted: 30 October 2015 - Published: 12 November 2015

\begin{abstract}
Wet atmospheric depositions have been collected in a rural (Katsiveli) and urban (Sevastopol) location at the Crimean coast of the Black Sea from 2003 to 2008. Samples, 217 from Katsiveli and 228 from Sevastopol, have been analysed for inorganic fixed nitrogen (nitrate, nitrite, and ammonium). Data have revealed almost equal contributions of ammonium (44-45\%) and nitrate (52-53\%) and minor contribution of nitrite (2-4\%) for both rural and urban samples. The volume weight mean concentration of inorganic fixed nitrogen (IFN) in urban samples $\left(2.51 \mathrm{mg} \mathrm{NL}^{-1}\right)$ is about 2fold of that content in rural samples $\left(1.16 \mathrm{mg} \mathrm{NL}^{-1}\right)$. Seasonal variations in volume weight mean monthly concentrations have been revealed for both locations with maximum concentrations in winter and minimum values in summer, but intra-annual variations are statistically significant for only urban samples.
\end{abstract}

The average annual deposition of IFN with atmospheric precipitations on the surface of the Black Sea is about $0.31 \times 10^{6} \mathrm{t} \mathrm{N} \mathrm{yr}^{-1}\left(0.75 \mathrm{t} \mathrm{N} \mathrm{km}^{-2} \mathrm{yr}^{-1}\right)$, which is on average $39 \%$ of the riverine input. It does vary in space and time. The relative importance of the atmospheric input increases from coastal to open areas and from winter to summer. Deposition of IFN with wet atmospheric precipitations proportionally increases the concentration of chlorophyll $a$, as it is traced from satellite data. The traced increase in the concentration of chlorophyll $a$ has reached 1.5-fold for mesoscale processes. In case of individual rain events supporting up to $50-60 \mathrm{mg} \mathrm{N} \mathrm{m}^{-2}$, the influence of IFN deposition is up to $5 \%$ at the north-western shelf of the Black Sea, where most of the river-born IFN is loaded. In the central areas of the sea, where the amount of IFN in summer is low, the contribution of individual rainfall can reach $35 \%$. The input of IFN to the Black Sea has potential to enhance 2-fold the level of primary production.

\section{Introduction}

The importance of atmospheric input of nutrients to marine environments has been revealed and demonstrated for both oligotrophic (Guerzoni et al., 1999) and even eutrophic systems (Langner et al., 2009). For the Black Sea, this source of nutrients has been scarcely accounted (Medinets and Medinets, 2012), and neither its overall significance, nor its spatial and seasonal variations have ever been studied. Such data are very important for understanding, modelling and assessing negative impacts of anthropogenic eutrophication as well as other effects in the Black Sea ecosystem.

The major considered sources of nutrients for marine environments are usually limited to riverine and coastal inputs, as well as recycling of organic matter in the water column and upper layer of sediments. It has been found that dry and wet atmospheric precipitations can be an important source of nutrients to open offshore areas (Donaghay et al., 1991; Duce et al., 2008). When it comes to relative inputs, atmospheric precipitation has been expectedly found important for oligotrophic Mediterranean Sea (Guerzoni et al., 1999), but this input has appeared important even for highly eutrophic marine systems, like the Baltic Sea (Rolff et al., 2008; Langner et al., 2009). However, in case of the Black Sea, only riverine input and respiration of organic matter have been practically considered (Cociasu et al., 1996; Konovalov et al., 1999; 
Konovalov and Murray, 2001). Though scarce published data (Kubilay et al., 1995; Chaykina et al., 2006; Medinets and Medinets, 2012) demonstrate an input of inorganic fixed nitrogen (IFN) with atmospheric precipitations, neither basinwide magnitude, nor after-effects of this input to the Black Sea have been ever evaluated.

The Black Sea is extremely important for the regional economy. This is primarily due to the possibility to use its mineral and biological resources and recreational and transport potentials. Where it comes to biological resources and ecological problems of any marine system, the knowledge on the flows of carbon and nutrients is of primary importance. The Black Sea has been documented for various environmental problems (Mee, 1992; Konovalov et al., 1999) due to heavy loads of nutrients. Though the riverine input of nutrients has decreased several-fold (Mee et al., 2005), the system remains suppressed or reveals only minor positive changes (Friedrich et al., 2014), assuming the presence of unaccounted sources of nutrients.

Jickells (1995) reviewed published data to show a dramatic increase in the atmospheric IFN fluxes in the 20th century and to demonstrate that atmospheric inputs could contribute $5-25 \%$ of the nitrogen requirement for new production. A number of studies have been completed over the last 2 decades to show that this source can account for $60 \%$ of the total continental supply of IFN to the oligotrophic Mediterranean (Guerzoni et al., 1999), but it may also reach $8 \%$ for the highly eutrophic Baltic Sea (Langner et al., 2009). It can level riverine inputs and support a large short-term increase in phytoplankton growth under certain meteorological conditions (Spokes and Jickells, 2005).

Observational data on the deposition of IFN with atmospheric precipitations at the surface of the Black Sea have been limited until recently to very few publications (Kubilay et al., 1995; Chaykina et al., 2006; Medinets and Medinets, 2012) and scarce information in cruise reports and unpublished data (Fig. 1). Kubilay et al. (1995) published the first known data on the content of oxidized IFN (nitrate and nitrite) in the Black Sea aerosols. Applying several assumptions on deposition velocities, annual rainfall and scavenging ratios, Kubilay et al. (1995) estimated the atmospheric deposition of oxidized IFN to reach $44100 \mathrm{t} \mathrm{Nyr}^{-1}$, mostly in wet form $(77 \%)$, which is up to $13 \%$ of the total IFN input of the Danube River, the major considered source of nutrients to the Black Sea (Cociasu et al., 1996). Medinets and Medinets (2012) have published their estimates of the IFN atmospheric input based on samples collected near the mouth of the Danube River in 2004-2010. They estimated the annual IFN input of $0.69 \pm 0.045 \mathrm{t} \mathrm{N} \mathrm{km}^{-2}$, mostly in dry form (up to $80 \%$ ). Im et al. (2013) have used the WRF/CMAQ modelling system and estimated the IFN atmospheric deposition in dry and wet form for the year of 2008 by the value of $0.82 \mathrm{~kg} \mathrm{~N} \mathrm{~km}^{-2}$. Im et al. (2013) have also concluded that dry deposition dominates over wet deposition in line with data published by Medinets and Medinets (2012), but against all other observational data for the Mediterranean (Guerzoni et al., 1999), Black Sea (Kubilay et al., 1995), and North Sea (de Leeuw et al., 2003). However, neither published data on spatial variations in the atmospheric input of IFN, nor information on effects of this deposition is available.

The chemical composition of wet atmospheric precipitations and the input on IFN depend on both long-range atmospheric transport and scavenging below clouds during atmospheric precipitation (Bertrand et al., 2008). Atmospheric transport in the Black Sea region is dominated by trajectories from Eastern Europe (38\%), Russia (33\%), local region (19\%), and North Africa (10\%) (Kubilay et al., 1995). Three major long-range transport trajectories account for $90 \%$ of precipitation events, and these trajectories cross areas with rather equal, yet seasonally variable, magnitude of anthropogenic IFN emission (Im et al., 2013). This means that longrange transport is important for seasonal variations in the content of IFN in the atmosphere and its input to the Black Sea, but local processes of scavenging below clouds on time of precipitation are important for regional spatial and shortterm temporal variations.

This paper is aimed (i) to present multi-annual observational data set of IFN (ammonium, nitrate and nitrite) with wet atmospheric deposition in an urban (Sevastopol) and rural (Katsiveli) sites of the Crimean coast of the Black Sea; (ii) to analyse interannual, seasonal, and mesoscale variations in IFN deposition; (iii) to parameterize this deposition; and (iv) to evaluate impact of IFN deposition to the Black Sea on various timescales.

\section{Data and methods}

\subsection{Sampling sites and observational data}

Monitoring of wet atmospheric precipitations and analysis of IFN (nitrate, nitrite, ammonium) has been organized in Katsiveli (southern coast of Crimea) and Sevastopol (western coast of Crimea) from 2003 to 2008 (Fig. 1). While samples from Katsiveli represent rural conditions, those from Sevastopol are representative of urban conditions.

Katsiveli (http://en.wikipedia.org/wiki/Katsiveli) is a settlement of about 650 permanent residents. It is located right at the sea coast and at a distance of $100 \mathrm{~km}$ from the nearest largest cities (Sevastopol, Simferopol, and Yalta). Besides, this site is protected by $600-1100 \mathrm{~m}$ high cliffs from northern and north-western winds, to additionally block urban air pollution.

Sevastopol (http://en.wikipedia.org/wiki/Sevastopol) is one of the largest and industrially developed cities of Crimea. There are about 385000 permanent residents, but this population can easily triple during summer time.

Wet atmospheric precipitations of every single rain have been collected. Sample collection procedure conformed to requirements of EMEP (Berg et al., 2001). Over the period of 


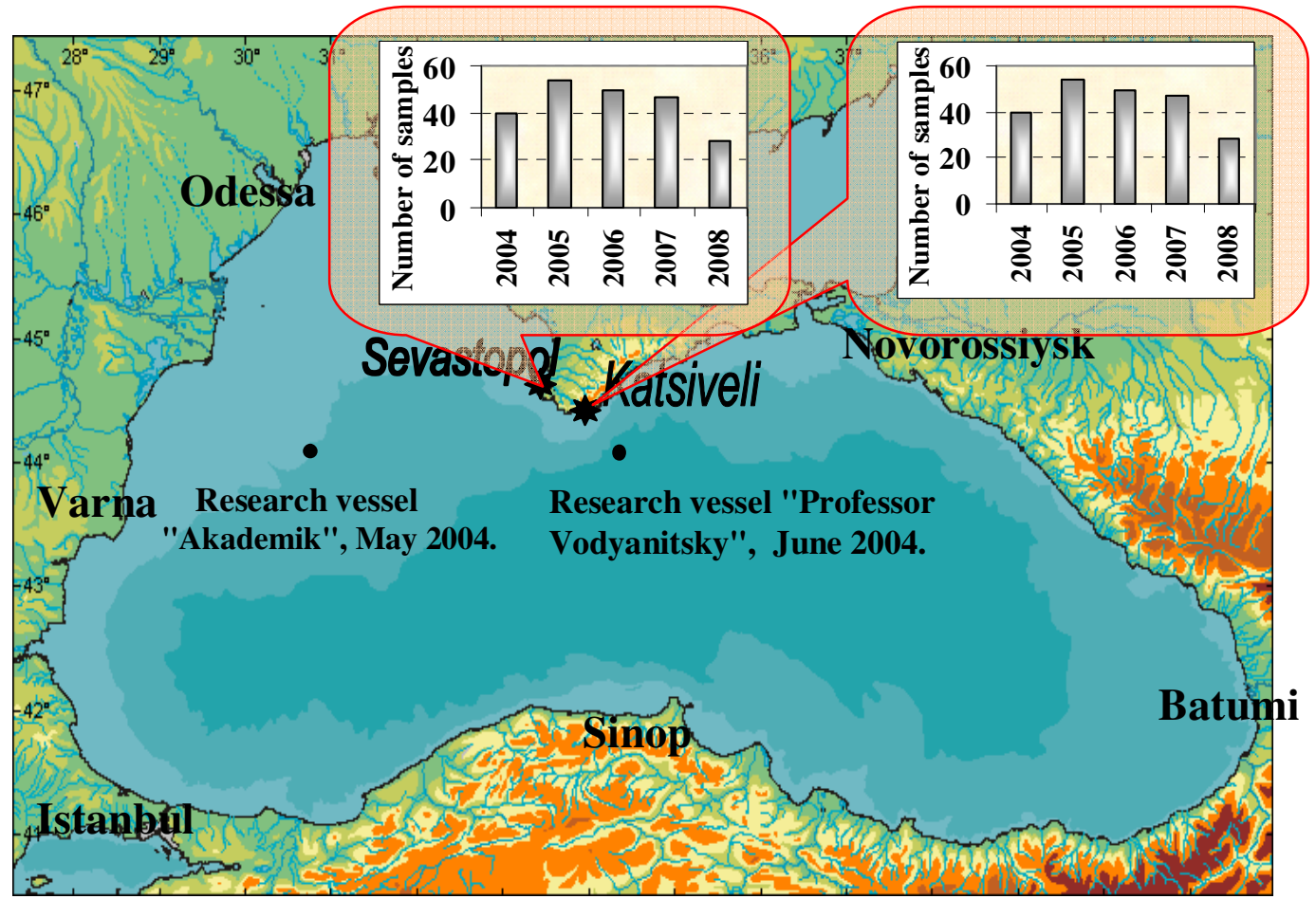

Figure 1. Monitoring sites in Sevastopol and Katsiveli $\left(^{*}\right)$ and off-shore sampling locations $(\bullet)$. Data from off-shore locations and from Odessa have been used to verify the multiple regression equation.

2003-2008, 228 and 217 samples of atmospheric precipitations were collected to carry out 684 and 651 chemical analyses in Sevastopol and Katsiveli, respectively. The number of samples per year varied from 25 to 54, except for Sevastopol in 2003, when the number of samples was 10 (Fig. 1).

The sampler was open for collection of wet atmospheric precipitations and closed on other time in Sevastopol. The sampler collected dry and wet atmospheric deposition in Katsiveli, because expected dry precipitations of IFN were 23$33 \%$ of wet deposition (Kubilay et al., 1995; Guerzoni et al., 1999). To verify and compare data, 17 samples were collected in parallel with a permanently open sampler for dry and wet precipitations in Sevastopol. Though an elevated fraction of dry forms of atmospheric precipitations was expected for Sevastopol, an urban site, the concentration was only 0 to $30 \%$ (average $14 \%$ ) higher for samples of bulk deposition, as compared to samples of only wet precipitations. This is exactly in line with published data for the Mediterranean (Guerzoni et al., 1999), Black (Kubilay et al., 1995), and North (de Leeuw et al., 2003) seas. But Medinets and Medinets (2012) reported dry deposition to reach 40 to $80 \%$ of bulk deposition of IFN for the north-western part of the Black Sea.

The collected samples were analysed for nitrate, nitrite, and ammonium concentrations following standard analytical procedures (Berg et al., 2001). The operational reproducibility was $2.9 \%$ and accuracy was $2.0 \%$ for nitrite, 12.5 and
$20.0 \%$ for nitrate, and 3.1 and $9.0 \%$ for ammonium. Primary data were quality verified and statistically filtered to eliminate potentially erroneous and/or abnormal results applying the $3 \sigma$ rule. Thus, three values were discarded for Sevastopol, but no data were discarded for Katsiveli.

The maximum concentrations of nitrate in Sevastopol and Katsiveli (3.41 and $2.94 \mathrm{mg} \mathrm{NL}^{-1}$ ) were detected in December 2006 and April 2005, respectively. The minimum values $\left(0.10\right.$ and $\left.0.21 \mathrm{mg} \mathrm{NL}^{-1}\right)$ were determined in rainwater in June 2008 and October 2006. The maximum (3.95 and $\left.3.85 \mathrm{mg} \mathrm{NL}^{-1}\right)$ and minimum $\left(0.08\right.$ and $\left.0.01 \mathrm{mg} \mathrm{NL}^{-1}\right)$ concentrations of ammonium were revealed in February and December 2004 in Sevastopol and in July 2007 and May 2004 in Katsiveli. There were 7 cases in Sevastopol and 10 cases in Katsiveli of the nitrite concentration below its detection limit. But maximum concentrations were detected in December $2006\left(0.24 \mathrm{mg} \mathrm{NL}^{-1}\right)$ in Sevastopol and in November $2005\left(0.09 \mathrm{mg} \mathrm{NL}^{-1}\right)$ in Katsiveli. The sum of IFN species reached its minimum $\left(0.36\right.$ and $\left.0.26 \mathrm{mg} \mathrm{NL}^{-1}\right)$ in February 2004 and February 2007 in Sevastopol and Katsiveli accordingly. The maximum values (5.94 and $2.96 \mathrm{mg} \mathrm{NL}^{-1}$ ) were detected in July 2006 and November 2005.

Of all collected samples, $65 \%$ were collected from October to March and $45 \%$ - from April to September making it possible to trace intra-annual variations (Fig. 2.).

Meteorological data were also recorded for the rate of precipitation, wind speed and direction, air temperature, pres- 


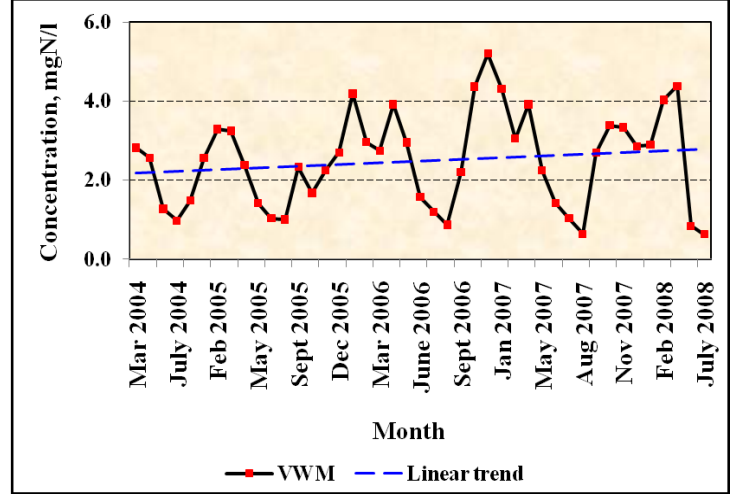

a)

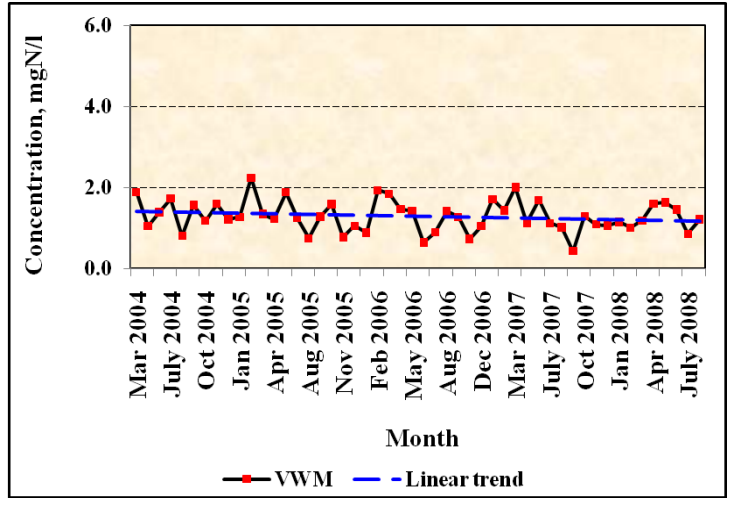

b)

Figure 2. Monthly volume-weighted mean IFN concentrations in atmospheric precipitations in Sevastopol (a) and Katsiveli (b).

sure and relative humidity making possible statistical and regression analyses.

\subsection{Multiple regression analysis}

In order to analyse spatial and temporal variations in the input of IFN to the Black Sea with atmospheric precipitations and to scale the effect of this input, we have followed Vautz et al. (2003) to parameterize the concentration of IFN as a function of meteorological variables. A multiple regression equation is used in this model to bind meteorological parameters (daily data of the precipitations amount, wind direction, season and preceding dry period) with the flow of contaminants from the atmosphere.

Many studies have been published assessing the influence of meteorological parameters on the concentration of IFN in atmospheric precipitations. One of the most important parameters is the rate of precipitation (Sweet et al., 1999). Beverland (1998) and later Garban (2004) assessed this dependence by the power law in Eq. (1).

$C=a \cdot x^{b}$,

where $C$ is the concentration of IFN in atmospheric precipitations; $x$ is the rate of precipitations; $a$ and $b$ are specific coefficients, which are individual for sampling sites.

Jenkins et al. (2006) demonstrated that nitrate concentrations in rainwater depend on local weather patterns. Padgett et al. (2008) studied the effect of storm duration and wind direction. The influence of the wind speed on mineralization of atmospheric depositions could be approximated by the thirdor fourth-order power law (Abesalashvili et al., 2001).

In order to reconstruct a multiple nonlinear regression equation for the IFN concentration as a function of meteorological parameters, we have followed the approach discussed by Vautz et al. (2003) and suggested by Brandon (1959). The method is based on (i) identification of regressions between the concentration of IFN and individual statistically significant meteorological variables and (ii) successive introduc- tion of these individual regressions to the multiple regression equation.

Four meteorological variables (precipitation rate, wind speed, wind direction, and relative humidity) have been identified of having relevant and statistically significant influence on the concentration of IFN in samples of rainwater. They have been successively introduced to the multiple non-linear regression equation (Eq. 2), and their contributions have been evaluated. The influence of the rate of atmospheric precipitation is expectedly the highest one (Sweet et al., 1999), and it reaches $68 \%$. The contributions of other components are comparable, and they equal 12, 10 and $10 \%$ for the wind speed, wind direction and relative humidity, respectively.

$$
\begin{aligned}
& C=1.0826 \cdot \exp ^{-0.0496 \cdot R_{i}} \cdot\left(0.0012 \cdot V_{x}^{3}-0.008 \cdot V_{x}^{2}\right. \\
& \left.-0.0221 \cdot V_{x}+1.1071\right) \\
& \times\left(0.0004 \cdot V_{y}+0.9535\right) \cdot(-0.0006 \cdot f+0.96),
\end{aligned}
$$

where $R_{i}$ is the daily precipitation amount, $\mathrm{mm} ; V_{x}$ and $V_{y}$ are latitudinal and longitudinal wind components; $f$ is relative humidity, $\%$.

This equation has been verified against observational data from Sevastopol, Katsiveli and Odessa, other published data (Medinets at Medinets, 2012) and unpublished data from scientific cruises (Fig. 1). It has been found that the difference between calculated and measured values is under $14 \%$ and does not exceed analytical errors.

\subsection{Meteorological data, satellite images, and surface seawater chemistry}

Information on precipitation, wind, and relative humidity has been taken from http://meteocenter.net, http://www. wetterzentrale.de and http://rp5.ua to quantify the input of IFN to the Black Sea with wet precipitations.

To assess the effect of atmospheric deposition for the distribution of IFN in the surface layer of the Black Sea, data from the National Oceanographic Data Center (http://ocean. 


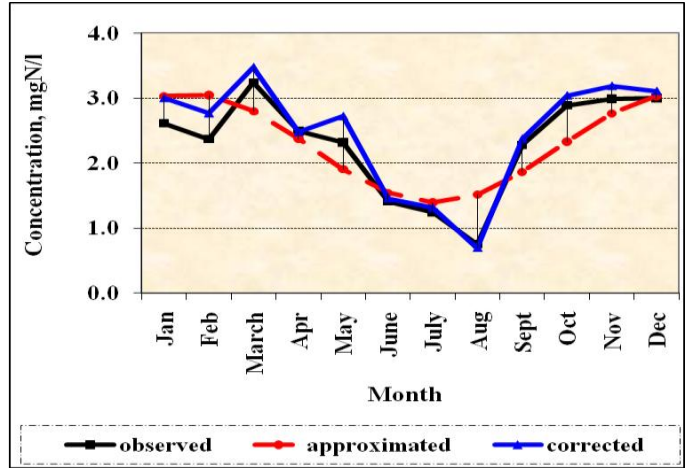

a)

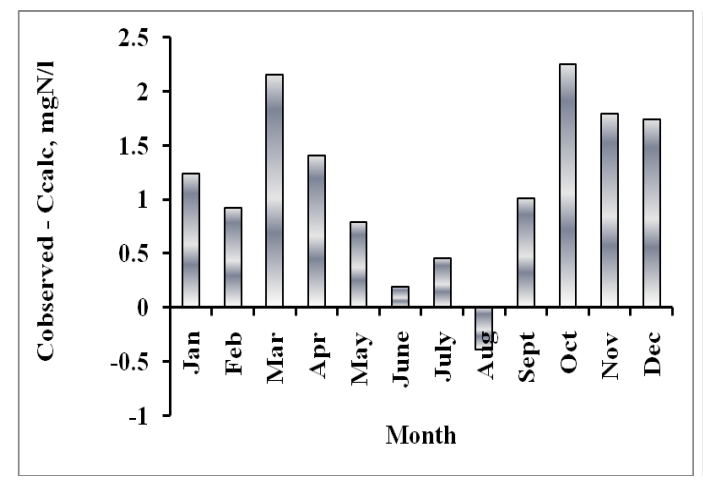

c)

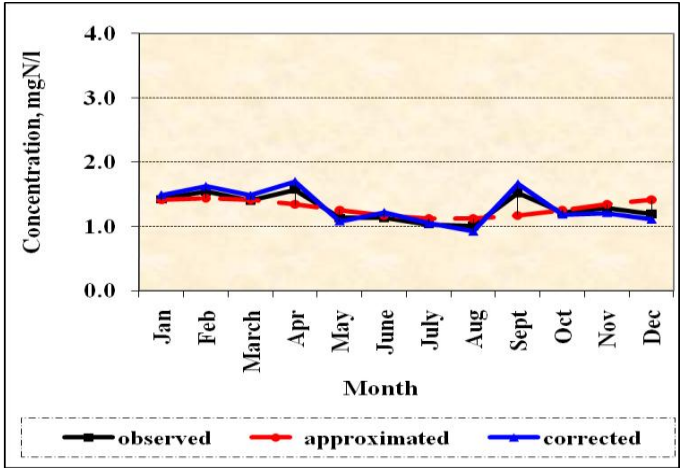

b)

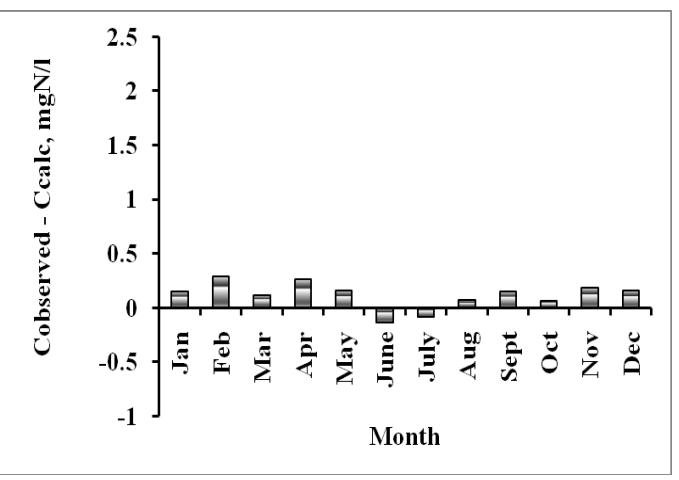

d)

Figure 3. Intra-annual variations in monthly volume-weighted mean IFN concentrations (observed, corrected for variations in the rate of precipitation, and approximated by a Cosine function) in Sevastopol (a) and Katsiveli (b); the difference between the observed and calculated IFN concentrations in atmospheric depositions for individual months in Sevastopol (c) and in Katsiveli (d).

nodc.org.ua/) for the period of 1990-2000 have been used to plot the average distributions of ammonium, nitrate and total IFN in the upper active layer of the sea in cold (NovemberMarch) and warm (April-September) periods of the year.

Satellite data (http://gdata1.sci.gsfc.nasa.gov/daac-bin/ G3/gui.cgi?instance_id=ocean_8day) on the distribution of pigments have been used to evaluate the influence of atmospheric IFN deposition on the concentration of chlorophyll $a$ in the surface waters. And satellite data on the sea surface temperature (http://podaac.jpl.nasa.gov/datasetlist? search=Pathfinder) have been used to separate and compare the effects of atmospheric deposition and upwelling.

\section{Results and discussion}

\subsection{IFN speciation, average concentrations and temporal variations}

Atmospheric depositions of IFN in Sevastopol and Katsiveli were mainly presented in 2004-2008 by nitrate (52-53\%) and ammonium $(44-45 \%)$. Nitrite was in the range of 2$4 \%$ presenting, most probably, intermediate products of ox- idation of ammonium to nitrate. The difference in these values between Sevastopol (urban site) and Katsiveli (rural site) is statistically insignificant. These values are typical for both the Black (Medinets and Medinets, 2012) and Mediterranean (Guerzoni et al., 1999) seas. For the Black Sea, Medinets and Medinets (2012) report the average contribution of $64.4 \pm 9.2 \%$ of ammonium, $35.3 \pm 9.1 \%$ of nitrate, and only $1.7 \pm 0.1 \%$ of nitrite to the content of IFN in atmospheric bulk depositions, but $46.0 \pm 15.3 \%$ of nitrate, $53.9 \pm 15.3 \%$ for ammonium, and $<0.2 \%$ for nitrite in wet depositions in 2004-2010. Thus, our data fit exactly the range of regional values reported for wet depositions. Our data are also in good agreement with those reported for the North Sea (Jickells, 1995), the eastern Mediterranean (Cre$\tan )$ Sea (Guerzoni et al., 1999), and the northern Levantine Basin (Koçak et al., 2010).

The calculated average annual input of IFN in 2003-2008 for rural areas (Katsiveli) was about $0.36 \mathrm{t} \mathrm{N} \mathrm{km}^{-2} \mathrm{yr}^{-1}$ and for urban areas (Sevastopol) - about $0.56 \mathrm{t} \mathrm{N} \mathrm{km}^{-2} \mathrm{yr}^{-1}$.

Interannual variations in monthly volume weighted mean concentrations of IFN in atmospheric precipitations are expected and have been traced both in Sevastopol and Kat- 
siveli (Fig. 2). They depend on seasonal variations in meteorological conditions, but they are also related to seasonal oscillations in anthropogenic emission from remote and local sources. The range of oscillations in the volume-weighted mean concentrations exceeds $4.5 \mathrm{mg} \mathrm{NL}^{-1}$ for Sevastopol, but it is about $1.8 \mathrm{mg} \mathrm{NL}^{-1}$ for Katsiveli. This suggests an important influence of local sources related to seasonal variations in fuel combustion, which is expectedly more important for urban areas. Besides, a slight (but statistically insignificant) interannual trend has been also traced in Sevastopol, but Katsiveli, from 2003 to 2008. This could be an evidence of increasing anthropogenic emission from local sources in Sevastopol, as compared to rural conditions in Katsiveli.

\subsection{Intra-annual variations and local sources}

The monthly volume weighted mean concentrations of IFN in atmospheric precipitations reveal the presence of similar seasonal oscillations in Sevastopol and Katsiveli (Fig. 3). Significantly higher concentrations are revealed in Sevastopol from November to March, as compared to summer (Fig. 3a). Though it is expected because the magnitude of anthropogenic emission (Martin et al., 2008) varies seasonally due to seasonal variations in fuel combustion, this feature has never been reported for the Black Sea. Whereas similar seasonal oscillations are revealed in Katsiveli, they are statistically insignificant (Fig. 3b). The absence of powerful local sources of air pollution is the very obvious explanation. Neither industrial, nor agricultural local sources are known for this rural site.

The monthly volume weighted mean concentrations of IFN increases from summer to winter (Fig. 3a and b), though the rate of wet precipitation also increases (Ivanov and Belokopytov, 2013). For both locations, the annual cycle has been approximated by a Cosine equation as a function of intra-annual period in radians. For Sevastopol, $C=$ $0.84 \cos (X-0.31)+2.23, R=0.67$. For Katsiveli, $C=$ $0.16 \cos (X-0.57)+1.28, R=0.37$. The maximum of approximated IFN concentration is in February.

If the magnitude of anthropogenic emission and other conditions do not vary, seasonal changes in the rate of precipitation would result in lower concentrations of IFN in wet precipitations in winter. The observed variations are opposite suggesting that the magnitude of anthropogenic emission dramatically increases from warm to cold seasons overwhelming all other factors. Despite the fact that the total amount of wet precipitation increases in winter, their intensity increases in summer. Indeed, if the average monthly concentrations, calculated for days with atmospheric precipitation, in Fig. 3 are normalized for the amount of summer precipitation, following the dependence of the concentration on the rate of precipitation (Eq. 2), the winter values increase 5$17 \%$ in Sevastopol and $5 \%$ in Katsiveli ("corrected" values in Fig. 3a and b).
The summer volume-weighted mean concentration of IFN is equal to $1.2 \pm 0.20 \mathrm{mg} \mathrm{NL}^{-1}$ in Katsiveli and $1.7 \pm 0.57 \mathrm{mg} \mathrm{NL}^{-1}$ in Sevastopol. The ratio of nitrate to ammonium is equal to 1.40 . From summer to winter, the volume-weighted mean concentration of total IFN increases to $2.8 \pm 0.25 \mathrm{mg} \mathrm{NL}^{-1}$ in Sevastopol, but it is 2-fold of the value in Katsiveli $\left(1.3 \pm 0.11 \mathrm{mg} \mathrm{NL}^{-1}\right)$. The ratio of nitrate to ammonium remains unchanged in Katsiveli, but it insignificantly increases to 1.50 in Sevastopol.

If the multiple regression (Eq. 2) is used to quantify the concentration of total IFN in wet precipitations (Fig. 3), the difference between the observed and calculated values is neither systematic nor in excess of analytical errors for Katsiveli (Fig. 3d). For Sevastopol, the observed and calculated values coincide within the range of analytical errors for summer, but the calculated values are systematically and significantly below the observed concentrations in winter (Fig. 3c). It fits the period and intensity of seasonal heating. When combined with data of the increased nitrate to ammonium ratio, it has revealed local sources of IFN to atmospheric wet precipitations in Sevastopol. Thus, the multiple regression (Eq. 2) provides correct estimates if significant local anthropogenic sources are absent. It is true for the off-shore part of the Black Sea and rural sites, but coastal areas can be under additional anthropogenic influence from large cities and ports.

There are several large industrial cities and sites of the scale of Sevastopol at or near the coastline of the Black Sea (Fig. 1): Istanbul, Varna, Constantsa, Odessa, Kerch, Novorossiisk, etc. To assess the extent of their influence, we have followed Izrael et al. (1987).

$C_{j}(x)=C_{j} \cdot \exp \left(\lambda_{j} x\right)$,

where $C_{j}$ is the maximum concentration of ingredient near the source $\left(\mathrm{mg} \mathrm{L}^{-1}\right) ; \lambda_{j}$ is the coefficient characterizing the rate of changing concentration $\left(\mathrm{km}^{-1}\right)$.

The value of $\lambda_{j}$ depends on the aerosol composition, wind speed and wind direction. For an average wind speed of about $5 \mathrm{~m} \mathrm{~s}^{-1}$, values of $\lambda_{j}$ can be calculated:

$\lambda_{j}=k \cdot \exp (-0.025 \cdot \eta)$,

where $k$ is the coefficient characterizing the aerosol composition (for example, $k=0.35$ for nitrate and ammonium); $\eta$ is the wind direction frequency in $\%$.

We have found that the effect of local sources associated with large cities for typical conditions of Sevastopol is limited to coastal zone within $25 \mathrm{~km}$ distance. Despite the fact that local sources have no significant direct effect on off-shore areas of the sea, monitoring of IFN deposition remains important to correctly evaluate the budget of nitrogen in coastal waters near industrial sites. It is specifically true for winter, when these sources are most significant. Thus, the input of IFN to the major off-shore part of the Black Sea can be correctly estimated applying the multiple regression (Eq. 2). 


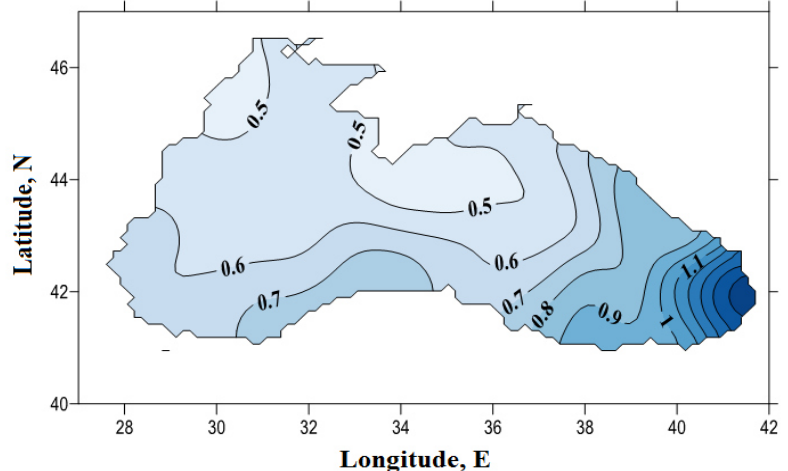

a)

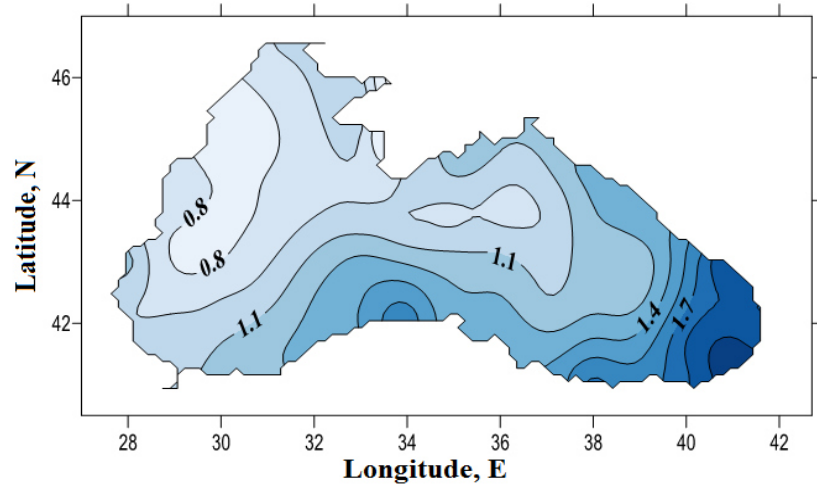

b)

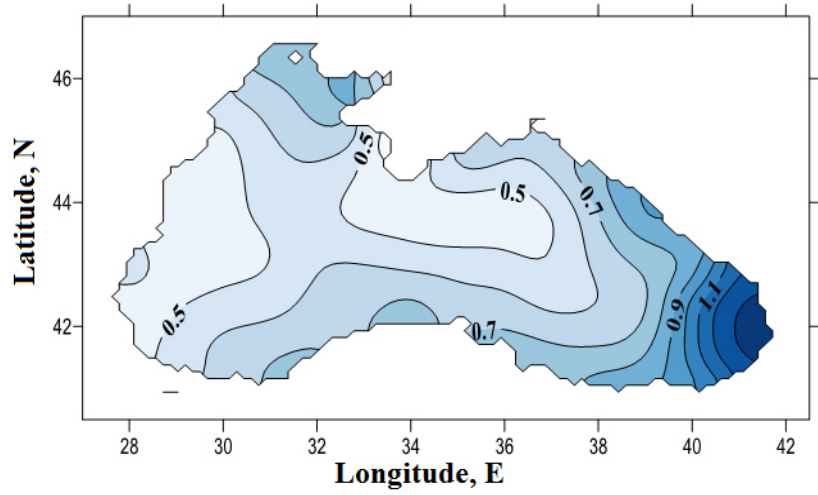

c)

Figure 4. The annual IFN deposition $\left(\mathrm{tNkm}^{-2} \mathrm{yr}^{-1}\right)$ with atmospheric precipitation at the Black Sea surface: the average values from 2004 to 2008 (a), the highest annual values in 2005 (b), the lowest annual values in 2008 (c).

This is specifically true and important for open off-shore areas, where direct observations for rain events and sampling are hardly possible.

\subsection{Input of IFN, its spatial and temporal variations, and importance for the nitrogen budget}

Applying Eq. (2) to calculate the concentration of IFN in wet atmospheric precipitations for regional meteorological conditions and multiplying this concentration by the rate of pre-
Table 1. The deposition of IFN at the Black Sea surface.

\begin{tabular}{lcc}
\hline Year & IFN deposition, $\mathrm{t} \mathrm{N} \mathrm{yr}^{-1}$ & \% of the annual input \\
\hline 2004 & $0.33 \times 10^{6}\left(0.79 \mathrm{t} \mathrm{N} \mathrm{km}^{-2} \mathrm{yr}^{-1}\right)$ & $29-49$ \\
2005 & $0.38 \times 10^{6}\left(0.91 \mathrm{t} \mathrm{k} \mathrm{km}^{-2} \mathrm{yr}^{-1}\right)$ & $34-57$ \\
2006 & $0.28 \times 10^{6}\left(0.67 \mathrm{t} \mathrm{k} \mathrm{km}^{-2} \mathrm{yr}^{-1}\right)$ & $25-42$ \\
2007 & $0.31 \times 10^{6}\left(0.73 \mathrm{t} \mathrm{k} \mathrm{km}^{-2} \mathrm{yr}^{-1}\right)$ & $28-46$ \\
2008 & $0.27 \times 10^{6}\left(0.65 \mathrm{t} \mathrm{km}^{-2} \mathrm{yr}^{-1}\right)$ & $24-40$ \\
Average & $0.31 \times 10^{6}\left(0.75 \mathrm{t} \mathrm{km}^{-2} \mathrm{yr}^{-1}\right)$ & $28-46$ \\
\hline
\end{tabular}

cipitation, we have quantified inputs of IFN for individual rain events. These results have been integrated over time or the sea to investigate spatial and temporal variations from the local to basin scale and from individual event to annual deposition.

The total amount of IFN deposited at the surface of the Black Sea over the period of observations (2004-2008) is about $1.55 \times 10^{6}$ th of nitrogen, which is on average about $0.75 \mathrm{tNkm}^{-2} \mathrm{yr}^{-1}$. It does vary in space and time (Fig. 4). Spatial variations mainly depend on the distribution of precipitations over the sea. The rate of atmospheric precipitations (Ivanov and Belokopytov, 2013) increases from the coast of Romania and Crimea to the coast of Turkey, but it reaches the highest values in the south-eastern part of the sea near Batumi. Similar spatial variations have been revealed for the magnitude of IFN deposition.

When it comes to individual years (Fig. 4), the overall pattern of spatial variations in the deposition of IFN remains similar, but interannual variations in meteorological conditions result in substantial spatial variations and even in 1.5-fold variations in the total deposition from $0.27 \times 10^{6} \mathrm{t} \mathrm{Nyr}^{-1}\left(0.65 \mathrm{t} \mathrm{k} \mathrm{km}^{-2} \mathrm{yr}^{-1}\right)$ in 2008 to $0.38 \times 10^{6} \mathrm{t} \mathrm{Nyr}^{-1}\left(0.91 \mathrm{t} \mathrm{N} \mathrm{km}^{-2} \mathrm{yr}^{-1}\right)$ in 2005 (Table 1$)$. For comparison, the value of $1.04 \mathrm{t} \mathrm{k} \mathrm{km}^{-2} \mathrm{yr}^{-1}$ has been reported for the North Sea (de Leeuw et al., 2003), $0.40 \mathrm{t} \mathrm{N} \mathrm{km}^{-2} \mathrm{yr}^{-1}$ for the Baltic Sea (Rolff et al., 2008), 1.6$2.6 \mathrm{t} \mathrm{N} \mathrm{km}^{-2} \mathrm{yr}^{-1}$ for the Mediterranean Sea (Guerzoni et al., 1999). This makes the observed values for the Black Sea similar to those for other seas in the region.

The input with riverine waters is usually considered the major and sometimes the only source of IFN for the Black Sea. However, data in Table 1 reveal that the atmospheric input of IFN can account for 24-57\% (average $39 \%$ ) of the input with riverine waters. This is definitely an important contribution to the total budget of nitrogen.

The annual input of IFN to the Black Sea with the riverine waters is $0.67 \times 10^{6} \mathrm{t} \mathrm{Nyr}^{-1}$ (Gregoire et al., 2003 ) to $1.12 \times 10^{6} \mathrm{tNyr}^{-1}$ (Ludwig et al, 2009), with industrial and domestic sewage is $0.14 \times 10^{6} \mathrm{tNyr}^{-1}$ (http://www.blacksea-commission.org/). It has been reported that the input of IFN from the deep sea reaches $0.28 \times 10^{6} \mathrm{tNyr}^{-1}$ (Konovalov et al., 2000) to $0.51 \times 10^{6} \mathrm{t} \mathrm{Nyr}^{-1}$ (Gregoire et al, 2003). Thus, considering the average annual atmospheric input of $0.31 \times 10^{6} \mathrm{t} \mathrm{Nyr}^{-1}$ 
Table 2. Seasonal variations in deposition of IFN at the Black Sea surface.

\begin{tabular}{lcc}
\hline Season & $\begin{array}{c}\text { IFN deposition, } \\
\mathrm{tN} \mathrm{km}^{-2} \text { season }^{-1}(\min -\mathrm{max})\end{array}$ & $\begin{array}{c}\text { \% of the seasonal } \\
\text { riverine input }\end{array}$ \\
\hline Spring & $0.11-0.15$ & $16-22$ \\
Summer & $0.06-0.09$ & $13-19$ \\
Autumn & $0.21-0.24$ & $70-80$ \\
Winter & $0.17-0.19$ & $40-44$ \\
\hline
\end{tabular}

(Table 1), 41-60\% of the total input of IFN to the Black Sea is with the riverine waters, $7-10 \%$ with industrial and domestic wastewater, $15-31 \%$ due to physical exchange processes, and $15-22 \%$ with the atmospheric precipitations.

One of the consequences and evidence of this large atmospheric input is a slow response of the Black Sea ecosystem (Konovalov and Eremeev, 2012; Friedrich et al., 2014) to the reported decrease in the riverine load of IFN (Cociasu et al., 1996). The maximum concentration of nitrate in the Black Sea waters remains 1.5- to 2-fold of typical values in the 1960s before the beginning of intensive eutrophication (data from the 33rd cruise of RV Maria S. Merian) and the ecosystem remains highly eutrophic (Yunev et al., 2002) and oxygen deprived (Friedrich et al., 2014), which is the reason for questions on sources of nutrients. Indeed, even an immediate and complete elimination of coastal inputs of IFN would result in less than $50 \%$ of the total input. The reported 2- to 3-fold decrease in the riverine input (Cociasu, 1996) has resulted in only $15-25 \%$ decrease in the total input of IFN.

Another issue is related to spatial variations in the relative contribution of the atmospheric input of IFN (Spokes and Jickells, 2005). Riverine, industrial and domestic sources deliver IFN to coastal and estuarine areas. Only about $2.2 \%$ from the total riverine input (i.e. about $0.02 \times 10^{6} \mathrm{t} \mathrm{Nyr}^{-1}$ ) reaches the deep sea area (Gregoire et al., 2003) via lateral mixing and advection, yet it takes a few months. The rest is distributed in the Black Sea waters through processes of recycling and physical exchange at the timescale of years. Unlike these coastal sources, the atmospheric input provides IFN directly to the place of atmospheric precipitation and to the surface layer of active primary biological processes. Up to $0.08 \times 10^{6} \mathrm{t} \mathrm{Nyr}^{-1}$ of IFN is deposited to the surface waters of the open sea providing over 4-fold of the riverine contribution of IFN to these waters. Intra-annual variations in the rate of atmospheric precipitations (Ivanov and Belokopytov, 2013) with its maximum in autumn to winter and minimum in spring to summer result in similar seasonal variations in the atmospheric IFN deposition (Table 2).

While the average annual (Table 1) and seasonal (Table 2) atmospheric IFN deposition appear to level other major sources of nutrients to the Black Sea, a possibility of individual rain events to change the content of nutrients in the surface waters over short time periods is an open question. They have demonstrated that episodic atmospheric inputs can be up to $12 \mathrm{mg} \mathrm{N} \mathrm{m}^{-2}$ event $^{-1}$ of IFN or up to $0.012 \mathrm{mg} \mathrm{N} \mathrm{kg}^{-1}$ if mixed to $1 \mathrm{~m}$ (Donaghay et al., 1991).

The average for April-September content of IFN in the upper layer of the Black Sea varies from $100-200 \mathrm{mg} \mathrm{N} \mathrm{m}^{-2}$ in the open sea to $1500-3000 \mathrm{mg} \mathrm{N} \mathrm{m}^{-2}$ in coastal areas near the Danube and Dnieper rivers (Fig. 5a). The average values for November-March vary from $200 \mathrm{mg} \mathrm{N} \mathrm{m}^{-2}$ in the open sea to $1200 \mathrm{mg} \mathrm{N} \mathrm{m}^{-2}$ in coastal areas near the Danube and Dnieper rivers (Fig. 5b). Two individual rain events supporting similar IFN fluxes of up to $50-60 \mathrm{mg} \mathrm{N} \mathrm{m}^{-2}$ (Fig. 5c and d) can increase the concentration of IFN in the surface waters by up to $5 \%$ of its content at the north-western shelf of the Black Sea (Fig. 5e and f). This influence does not substantially vary from season-to-season because the background content of nutrients in coastal and shelf waters is high (Spokes and Jickells, 2005). In the central areas of the sea, where the amount of IFN especially during summer is low, the contribution of individual rainfall can reach $35 \%$ of the background content (Fig. 5e and f). This contribution is expectedly higher for summer time because the ambient content of nutrients is depleted in primary production processes from spring to summer.

\subsection{Deposition of IFN and mesoscale processes}

The revealed input of IFN with atmospheric precipitations should result in a substantial increase in the export production. Krishnamurthy et al. (2010) have reported $>25 \%$ of the export production due to atmospheric IFN input. De Leeuw et al. (2003) have reported the potential to promote primary production of $5.3 \mathrm{mmol} \mathrm{Cm}^{-2} \mathrm{day}^{-1}$ for an average deposition of $11.2 \mathrm{mg} \mathrm{Nm}^{-2} \mathrm{day}^{-1}$. Applying the Redfield $\mathrm{C}: \mathrm{N}$ ratio of $106: 16$ for newly generated organic matter in the Black Sea (Burlakova et al., 2003), an input of $50-60 \mathrm{mg} \mathrm{N} \mathrm{m}^{-2}$ in one rain event may result in additional primary production of $330-400 \mathrm{mg} \mathrm{C} \mathrm{m}^{-2}$ day $^{-1}$ increasing 2-fold the average primary production $310 \mathrm{mg} \mathrm{Cm}^{-2} \mathrm{day}^{-1}$ (Stelmakh et al., 1998). This increase should be several times higher for the central part of the sea during summertime, where and when the rate of primary production is dramatically decreased due to the lack of nutrients.

The influence of atmospheric deposition of IFN at the concentration of chlorophyll $a$ in the surface waters in the Black Sea has never been studied. The previously published data have attributed spatial anomalies in the distribution of chlorophyll $a$ to coastal sources of nutrients (Vasiliu et. al., 2012), physical flux of nutrients (Yunev et al., 2002), and dust deposition (Katara et al., 2008). Yet, an episodic input of up to $50-60 \mathrm{mg} \mathrm{N} \mathrm{m}^{-2}$ should also result in detectable mesoscale anomalies in the distribution of chlorophyll $a$ (Varenik et al., 2010). As an example, mesoscale variations in the distribution of the chlorophyll $a$ concentration after atmospheric precipitation in 31 May 2004 are shown on Fig. 6. The concentration of chlorophyll $a$ in the central part of the sea is about $0.4 \mathrm{mg} \mathrm{m}^{-3}$ and it increases towards the coastal area 


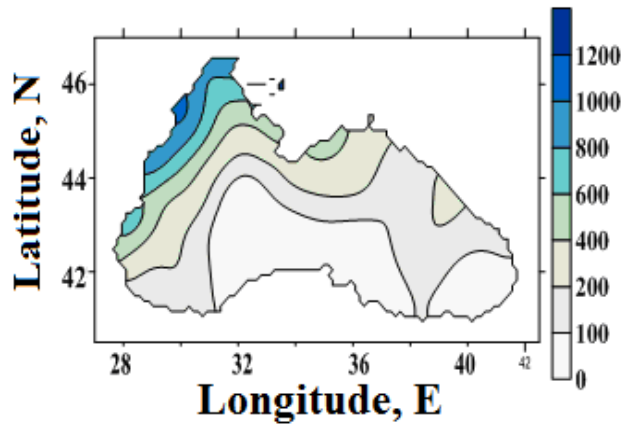

a)

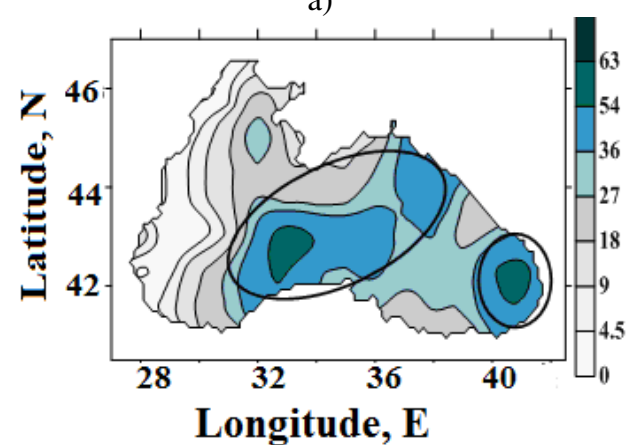

c)

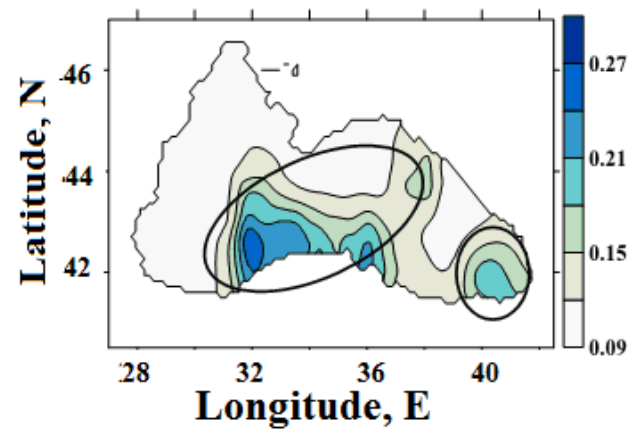

e)

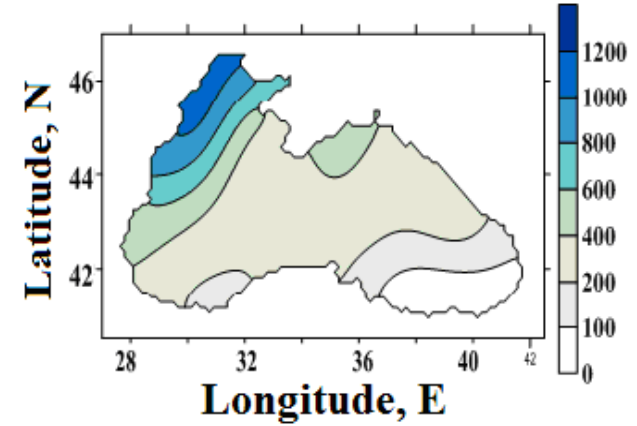

b)

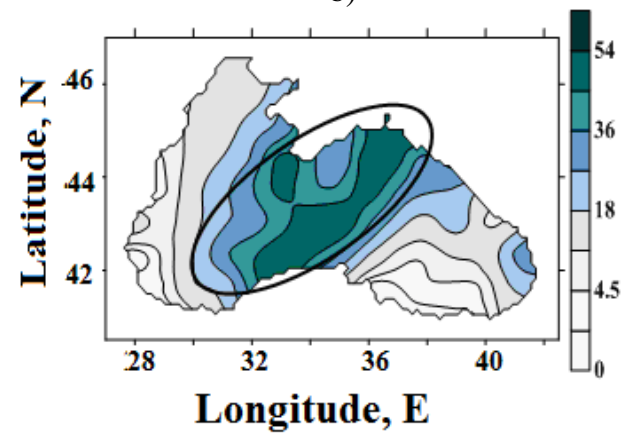

d)

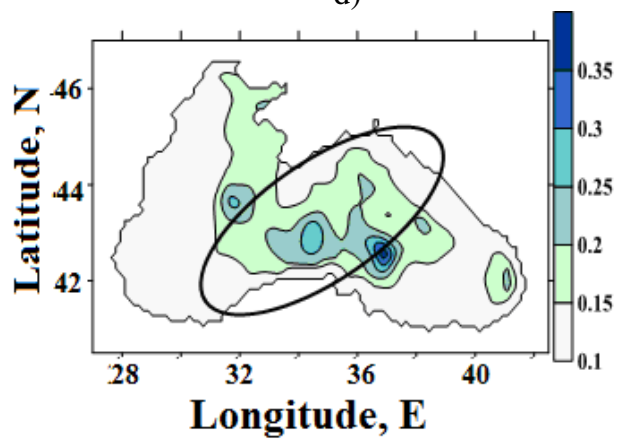

f)

Figure 5. The average IFN content in the upper $10 \mathrm{~m}$ layer of the sea in warm (a) and cold part of the year (b) $\left(\mathrm{mg} \mathrm{N} \mathrm{m}^{-2}\right)$, the deposition of IFN with atmospheric precipitations at the surface of the Black Sea in 12 August 2004 (c) and in 29 January 2007 (d) (mg N m ${ }^{-2}$ ) the ratio of the deposited amount of IFN to its average content in the upper $10 \mathrm{~m}$ layer of water (e, f). Oval figures represent regions of significant contributions to the IFN content in seawater.

(Fig. 6a). This is typical for the Black Sea in summer. It reflects the major coastal sources of nutrients, their active recycling in shallow parts of the sea, limited lateral exchange between coastal and open parts of the sea. As the result of rain on 31 May, the input of IFN with atmospheric precipitations at the surface of the Black Sea reached $1.85 \mathrm{mg} \mathrm{m}^{-3}$ for the central southern region (Fig. 6b), where typical concentrations of IFN (Fig. 5) and phytoplankton (Fig. 6) were low. It resulted in more intensive primary production. The concentration of chlorophyll $a$ in this area increased in several days (Fig. 6c). Then, the concentration of chlorophyll $a$ decreased to background values because fixed inorganic and organic nitrogen was gradually removed from the euphotic zone of this region (Fig. 6d) due to vertical export of particulate organic matter and lateral physical exchange.

In order to identify and separate the input of IFN with atmospheric precipitations from results of local upwelling, which may also lead to an increase of the IFN concentration in the surface waters, both the concentration of chlorophyll $a$ and temperature in the region have been traced. The temperature does not reveal any decrease, while the concentration of chlorophyll $a$ has increased by about $50 \%$ (Fig. 6c). The IFN input of $1.85 \mathrm{mg} \mathrm{m}^{-3}$ should result in $0.14 \mathrm{mg} \mathrm{m}^{-3}$ of chlorophyll $a$, as the input of $1 \mathrm{mmol}$ of IFN results in production of $1.05 \mathrm{mg}$ of chlorophyll $a$ (Gowen et al., 1992). It proves that the observed change in the chlorophyll $a$ concentration is the result of atmospheric precipitations of IFN. 


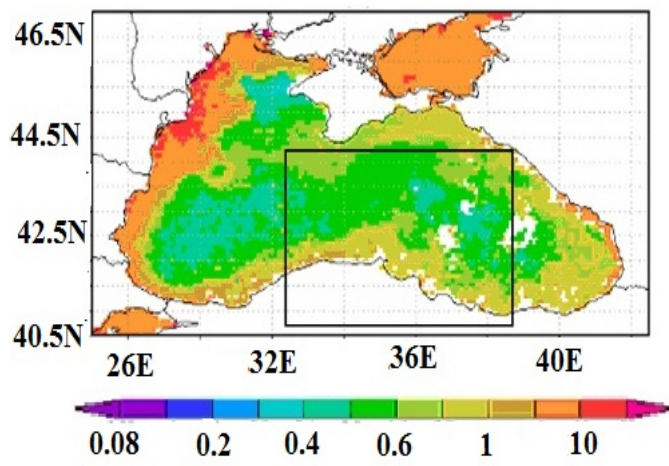

a

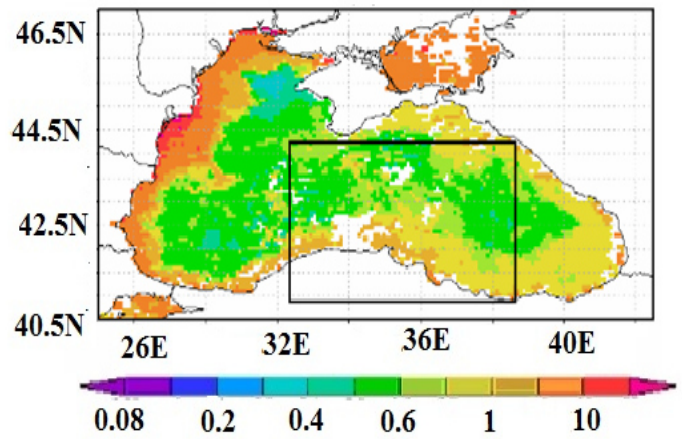

c

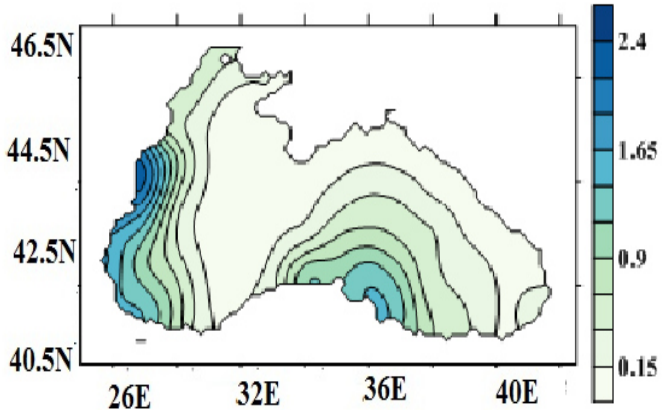

$\mathrm{b}$

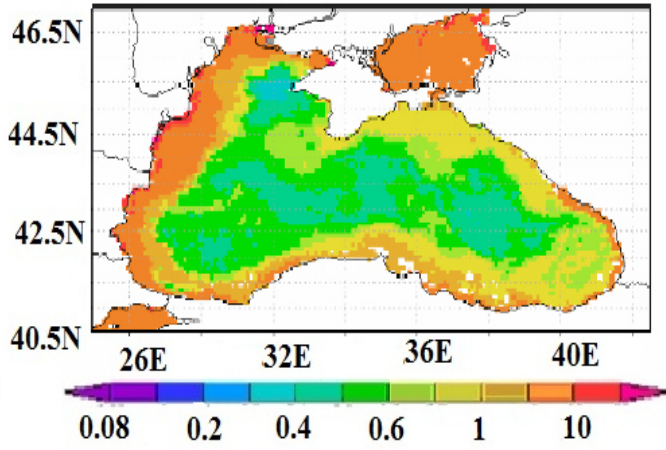

d

Figure 6. The atmospheric IFN input, $\mathrm{mg} \mathrm{Nm}^{-3}$, to the surface layer of seawater in 31 May 2004 (b) and averaged chlorophyll $a$ concentrations, $\mathrm{mg} \mathrm{m}^{-3}$, in 24-31 May 2004 (a), in 1-8 June 2004 (c), 17-24 June (d). Square figures represent the area of the maximum effect of the atmospheric IFN input.

Thus, the input of IFN with atmospheric precipitations does support active mesoscale processes and spatial patchiness of biological processes.

\section{Conclusions}

Atmospheric deposition of IFN in urban and rural locations at the Crimean coast of the Black Sea was mainly presented in 2004-2008 by nitrate (52-53\%) and ammonium (44$45 \%)$. Nitrite was in the range of $2-4 \%$. The difference in these values between urban and rural sites was statistically insignificant. The average total content of IFN in urban wet precipitations $\left(2.51 \mathrm{mg} \mathrm{NL}^{-1}\right)$ was about 2 -fold of that content in rural samples $\left(1.16 \mathrm{mgNL}^{-1}\right)$. The difference was mainly due to local sources, which were most active on winter time (Fig. 3).

The average annual input of IFN was $0.36 \mathrm{tNkm}^{-2} \mathrm{yr}^{-1}$ for rural areas and $0.56 \mathrm{t} \mathrm{N} \mathrm{km}^{-2} \mathrm{yr}^{-1}$ for urban areas in 2003-2008. Seasonal variations in average monthly concentrations have been revealed with maximum concentrations in winter and minimum values in summer, but intra-annual variations are statistically significant for only urban samples.
The input of IFN with atmospheric precipitations has been commonly neglected for the Black Sea because of the lack of regular observational data, significant riverine input and high eutrophic level of this marine system. Yet, it has been found that the annual deposition of IFN with atmospheric precipitations on the surface of the Black Sea is on average about $0.31 \times 10^{6} \mathrm{t} \mathrm{Nyr}^{-1}\left(0.75 \mathrm{t} \mathrm{N} \mathrm{km}^{-2} \mathrm{yr}^{-1}\right)$, which is $39 \%$ of the riverine input (Table 1). It does vary in space and time (Fig. 5). The magnitude of seasonal deposition of IFN with atmospheric precipitations varies from $0.06-0.09 \mathrm{t} \mathrm{N} \mathrm{km}^{-2}$ for summer to $0.21-0.24 \mathrm{t} \mathrm{N} \mathrm{km}^{-2}$ for autumn (Table 2).

In case of individual rain events supporting up to 50$60 \mathrm{mg} \mathrm{N} \mathrm{m}^{-2}$, the influence of IFN deposition is up to $5 \%$ of its background content in the upper $10 \mathrm{~m}$ layer of water at the north-western shelf of the Black Sea. In the central areas of the sea, where the amount of IFN during summer is low, the contribution of individual rainfall can reach $35 \%$. The input of IFN to the Black Sea has the potential to enhance 2-fold the level of primary production. The traced increase in the concentration of chlorophyll $a$ (Fig. 6) has reached 1.5-fold for mesoscale processes.

Thus, the results of this work demonstrate that the atmospheric sources of IFN are of great importance even for the 
highly eutrophic marine system of the Black Sea. This source of nutrients has to be accounted and monitored to correctly explain and forecast the Black Sea state and evolution.

Author contributions. A. Varenik analysed samples of wet precipitations, performed statistical analysis, plotted figures, and prepared the manuscript with contributions from all co-authors. S. Konovalov designed and planned the work, evaluated data, plotted figures, planned and contributed to the manuscript. S. Stanichny provided and supervised work with satellite data, contributed to the manuscript.

Acknowledgements. This work has been partially supported from RFBR project \#14-45-01008 for A. Varenik, RFBR project \#14-45-01001 for S. Konovalov, MESRF project \#14.604.21.0044 for S. Stanichny, and FANO project \#1002-2014-0010.

Edited by: S. W. A. Naqvi

\section{References}

Abesalashvili, L., Supatashvili, G., Salukvadze, T., and Salukvadze, M.: Hydrochemical characteristic of atmospheric precipitation in the Alazani Valley, Journal of the Georgian Geophysical Society, ISSN 1512-1127, Issue (B), Physics of Atmosphere, Ocean and Space Plasma, Geoprint, Publishing House, Tbilisi, vol. 5B, 56-62, 2001.

Berg, T., Dye, C., Hanssen, J. E., Munthe, J., Putaud, J.-P., Reissell, A., Schaug, J., Schmidbauer, N., Semb, A., Torseth, K., Uggerud, H. T., Yttri, K. E., and Aas, W.: EMEP manual for sampling and chemical analysis, EMEP/CCC-Report 1/95, NILU, Kjeller, Norway, November, 2001.

Bertrand, G., Celle-Jeanton, H., Laj, P., Rangognio, J., and Chazot, G.: Rainfall chemistry: long range transport versus below cloud scavenging. A two-year study at an inland station (Opme, France), J. Atmos. Chem., 60, 253-271, 2008.

Beverland, I. J., Crowther, J. M., Srinivas, M. S. N., and Heal, M. R.: The influence of meteorology and atmospheric transport patterns on the chemical composition of rainfall in south-east England, Atmos. Environ., 6, 1039-1048, 1998.

Brandon, D. B.: Developing mathematical models for computer control, Instrument Society of America Journal, 7, 176-203, 1959.

Burlakova, Z. P., Eremeeva, L. V., and Konovalov, S. K.: Inventory and fluxes of particulate organic carbon and nitrogen in the Black Sea oxic/anoxic water column, in: Oceanography of the Eastern Mediterranean and Black Sea, edited by: Yilmaz, A., Proceeding of the "Second International Conference on Oceanography of the Eastern Mediterranean and Black Sea: Similarities and Differences of Two Interconnected Basins", 14-18 October 2002, METU Cultural and Convention Center, Ankara, Turkey, TUBITAK Publishers, Ankara, Turkey, ISBN 975-288-451-2, 514-522, 2003.

Chaykina, A. V., Dolotov, V. V., Ilyin, Y. P., Konovalov, S. K., Kuznetsov, A. S., Repetin, L. N., and Voitsekhovich, O. V.: Ob- servational studies of nutrient loads on the Black Sea with atmospheric precipitations, in: Proceedings of the First Biannual Scientific Conference "Black Sea Ecosystem 2005 and Beyond", 8-10 May 2006, Commission on the Protection of the Black Sea Against Pollution, Istanbul, Turkey, 199-209, 2006.

Cociasu, A., Dorogan, L., Humborg, C., and Popa, L.: Long-term ecological changes in Romanian coastal waters of the Black Sea, Mar. Pollut. Bull., 32, 32-38, 1996.

Donaghay, P. L., Liss, P. S., Duce, R. A., Kester, D. R., Hanson, A. K., Villareal, T., Tindale, N. W., and Gifford, D. J.: The role of episodic atmospheric nutrient inputs in the chemical and biological dynamics of oceanic ecosystems, Oceanography, 4, 62-70, 1991.

Duce, R. A., LaRoche, J., Altieri, K., Arrigo, K., Baker, A., Capone, D. G., Cornell, S., Dentener, F., Galloway, J., Ganeshram, R. S., Geider, R. J., Jickells, T., Kuypers, M. M., Langlois, R., Liss, P. S., Liu, S. M., Middelburg, J. J., Moore, C. M., Nickovic, S., Oschlies, A., Pedersen, T., Prospero, J., Schlitzer, R., Seitzinger, S., Sorensen, L. L., Uematsu, M., Ulloa, O., Voss, M., Ward, B., and Zamora, L.: Impacts of atmospheric anthropogenic nitrogen on the open ocean, Science, 320, 893-897, 2008.

Friedrich, J., Janssen, F., Aleynik, D., Bange, H. W., Boltacheva, N., Çagatay, M. N., Dale, A. W., Etiope, G., Erdem, Z., Geraga, M., Gilli, A., Gomoiu, M. T., Hall, P. O. J., Hansson, D., He, Y., Holtappels, M., Kirf, M. K., Kononets, M., Konovalov, S., Lichtschlag, A., Livingstone, D. M., Marinaro, G., Mazlumyan, S., Naeher, S., North, R. P., Papatheodorou, G., Pfannkuche, O., Prien, R., Rehder, G., Schubert, C. J., Soltwedel, T., Sommer, S., Stahl, H., Stanev, E. V., Teaca, A., Tengberg, A., Waldmann, C., Wehrli, B., and Wenzhöfer, F.: Investigating hypoxia in aquatic environments: diverse approaches to addressing a complex phenomenon, Biogeosciences, 11, 1215-1259, doi:10.5194/bg-111215-2014, 2014.

Garban, B., Motelay-Massei, A., Blanchoud, H., and Ollivon, D.: A single law to describe atmospheric nitrogen bulk deposition versus rainfall amount: inputs at the Seine River watershed scale, Water Air Soil Poll., 155, 339-354, 2004.

Gowen, R. J., Tett, P., and Jones, K. J.: Predicting marine eutrophication: the yield of chlorophyll from nitrogen in Scottish coastal waters, Mar. Ecol.-Prog. Ser., 85, 153-161, 1992.

Gregoire, M., Beckers, J.-M., Fridrich, J., Konovalov, S., Kostianoy, A., Nezlin, Stanev, E. V., and Nihoul, J. C. J.: Nitrogen budget on the shelf and slope area of the Black Sea basin as inferred from modeling experiments, in: Oceanography of Eastern Mediterranean and Black Sea, edited by: Yilmaz, A., Proceeding of the Second International Conference on Oceanography of the Eastern Mediterranean and Black Sea: Similarities and Differences of Two Interconnected Basins", METU Cultural and Convention Center, Ankara, Turkey, 14-18 October 2002, TUBITAK Publishers, Ankara, Turkey, ISBN 975-288-451-2, Tubitak publ, 313-321, 2003.

Guerzoni, S., Chester, R., Dulac, F., Herut, B., Loÿe-Pilot, M. D., Measures, C., Migon, C., Molinaroli, E., Moulin, C., Rossini, P., Saydam, C., Soudine, A., and Ziverik, P.: The role of atmospheric deposition in the biogeochemistry of the Mediterranean Sea, Prog. Oceanogr., 44, 147-190, 1999.

Im, U., Christodoulaki, S., Violaki, K., Zarmpas, P., Kocak, M., Daskalakis, N., Mihalopoulos, N., and Kanakidou, M.: Atmo- 
spheric deposition of nitrogen and sulfur over southern Europe with focus on the Mediterranean and the Black Sea, Atmos. Environ., 81, 660-670, 2013.

Ivanov, V. A. and Belokopytov, V. N.: Oceanography of the Black Sea, ECOSY-Gidrofizika, Sevastopol, 17-19, 2013.

Izrael, Y. A., Nazarov, I. M., Fridman, S. D., Galperin, M. V., Pressman A, Y., Ryaboshapko, A. G., Vitkov, C. D., Gaspra, L., Harvath, L., Disher, H., Damrat, U., Zavodski, V., and Shantroch, Y.: Monitoring of the Transboundary Air Pollutant Transport, Hydrometeoizdat, Leningrad, 1987 (in Russian).

Jenkins, S., Gamble, D., Benedetti, M., and Willey, J.: The effects of local weather patterns on nitrate and sulfate rainwater concentrations in Wilmington, North Carolina, The North Carolina Geographer, 14, 29-38, 2006.

Jickells, T.: Atmospheric inputs of metals and nutrients to the oceans: their magnitude and effects, Mar. Chem., 48, 199-214, 1995.

Katara, I., Illian, J., Pierce, G. J., Scott, B., and Wang, J.: Atmospheric forcing on chlorophyll concentration in the Mediterranean, Hydrobiologia, 612, 33-48, 2008.

Koçak, M., Kubilay, N., Tugrul, S., and Mihalopoulos, N.: Atmospheric nutrient inputs to the northern levantine basin from a long-term observation: sources and comparison with riverine inputs, Biogeosciences, 7, 4037-4050, doi:10.5194/bg-7-40372010, 2010.

Konovalov, S. K. and Eremeev, V. N.: Monitoring of the Black Sea biogeochemical properties: major features and changes, in: Earth Systems Change over Eastern Europe, edited by: Groisman, P. Y. and Lyalko, V. I., ISBN 978-966-360-197-7, Akedemperiodyka, Kyiv, 363-385, 2012.

Konovalov, S. K. and Murray, J. W.: Variations in the chemistry of the Black sea on a time scale of decades (1960-1995), J. Marine Syst., 31, 217-243, 2001.

Konovalov, S. K., Ivanov, L. I., Murray, J. W., and Eremeeva, L. V.: Eutrophication: a plausible cause for changes in hydrochemical structure of the Black Sea anoxic layer, in: Environmental Degradation of the Black Sea: Challenges and Remedies, edited by: Besiktepe, S. T., Unluata, U., and Bologa, A., Proceedings of the NATO Advanced Research Workshop "Environmental Degradation of the Back Sea: Challenges and Remedies", ConstantaMamaia, Romania, 6-10 October 1997, NATO Science Series2, Environmental Security, Kluwer Academic Publishers, Dordrecht, the Netherlands, 56, 61-74, 1999.

Konovalov, S. K., Ivanov, L. I., and Samodurov, A. S.: Oxygen, nitrogen and sulphide fluxes in the Black Sea, Mediterranean Marine Science, 1/2, 41-59, 2000.

Krishnamurthy, A., Moore, J. K., Mahowald, N., Luo, C., and Zender, C. S.: Impacts of atmospheric nutrient inputs on marine biogeochemistry, J. Geophys. Res., 115, G01006, doi:10.1029/2009JG001115, 2010.

Kubilay, N., Yemenicioglu, S., and Saydam, A. C.: Airborne material collections and their chemical composition over the Black Sea, Mar. Pollut. Bull., 30, 475-483, 1995.

Langner, J., Andersson, C., and Engardt, M.: Atmospheric input of nitrogen to the Baltic Sea basin: present situation, variability due to meteorology and impact of climate change, Boreal Environ. Res., 14, 226-237, 2009.

de Leeuw, G., Spokes, L., Jickells, T., Skjoth, C. A., Hertel, O., Vignati, E., Tamm, S., Schulz, M., Sorensen, L.-L., Pedersen, B.,
Klein, L., and Schlünzen K. H.: Atmospheric nitrogen inputs into the North Sea: effect on productivity, Cont. Shelf Res., 23, 1743 1755, doi:10.1016/j.csr.2003.06.011, 2003.

Ludwig, W., Dumont, E., Meybeck, M., and Heussner, S.: River discharges of water and nutrients to the Mediterranean and Black Sea: Major drivers for ecosystem changes during past and future decades?, Prog. Oceanogr., 80, 199-217, 2009.

Martin, M. V., Honrath, R. E., Owen, R. C., and Li, Q. B.: Seasonal variation of nitrogen oxides in the central North Atlantic lower free troposphere, J. Geophys. Res., 113, D17307, doi:10.1029/2007JD009688, 2008.

Mee, L. D.: The Black Sea in a crisis: a need for concentrated international action, Ambio, 21, 278-285, 1992.

Mee, L. D., Friedrich, J., and Gomoiu, M. T.: Restoring the Black Sea in times of uncertainty, Oceanography, 18, 100-111, 2005.

Medinets, S. and Medinets, V.: Investigations of atmospheric wet and dry nutrient deposition to marine surface in western part of the Black Sea, Turk. J. Fish. Aquat. Sc., 12, 497-505, 2012.

Padgett, P. E. and Minnich, R. A.: Wet deposition of nitrogenous pollutants and the effect of storm duration and wind direction: a case study from inland Southern California, Water Air Soil Poll. 187, 337-341, 2008.

Rolff, C., Elmgren, R., and Voss, M.: Deposition of nitrogen and phosphorus on the Baltic Sea: seasonal patterns and nitrogen isotope composition, Biogeosciences, 5, 1657-1667, doi:10.5194/bg-5-1657-2008, 2008.

Spokes, L. J. and Jickells, T. D.: Is the atmosphere really an important source of reactive nitrogen to coastal waters?, Cont. Shelf Res., 25, 2022-2035, 2005.

Stelmakh, L. V., Yunev, O. A., Finenko, Z. Z., Vedernikov, V. I., Bologa, A. S., and Churilova, T. Yu.: Peculiarities of seasonal variability of primary production in the Black Sea, in: NATO TUBlack Sea Project Ecosystem Modeling as a Management Tool for the Black Sea, edited by: Ivanov, L. and Oguz, T., Proceedings of the NATO TU Black Sea Project "Ecosystem Modeling as a Management Tool for the Black Sea, Zori Rossii, Ukraine, 1519 June 1997, NATO ASI Series, Kluwer Academic Publishing, Dordrech, the Netherlands, 2/47(1), 93-104, 1998.

Sweet, S., Wade, T. L., Park, J., and Wylie, D.: Atmospheric deposition of nutrient nitrogen to Galveston Bay, Texas, in: Proceedings, Galveston Bay Estuary Program, State of the Bay Symposium IV, 28-29 January, Galveston, TX, 263-274, 1999.

Varenik, A. V., Konovalov, S. K., and Metik-Diyunova, V. V.: Prostranstvennoe raspredelenie potoka neorganicheskogo azota $\mathrm{s}$ atmosfernimi osadkami na poverhnost Chernogo morya (Temporal and spatial variations in the influence of atmospheric precipitation on the distribution of inorganic fixed nitrogen in the Black Sea surface waters), in: Ecological Safety of Coastal and Shelf Zones and Comprehensive Use of Shelf Resources: Collected Scientific Papers, Iss. 22, edited by: Ivanov, V. A., NAS of Ukraine, MHI, IGS, OD IBSS, Sevastopol, 268-273, 2010.

Vasiliu, D., Boicenco, L., Gomoiu, M. T., Lazar, L., and Mihailov, M. E.: Temporal variation of surface chlorophyll-a in the Romanian near-shore waters, Mediterranean Marine Science, 13, 213-226, doi:10.12681/mms.301, 2012.

Vautz, W., Busch, A. U., Urfer, W., and Klockow, D.: A statistical approach to estimate spatial distributions of wet deposition in Germany, Water Air Soil Poll., 145, 215-238, doi:10.1023/A:1023676011565, 2003. 
Yunev, O., Vladimir, A., Basturk, O., Yilmaz, A., Kideys, A. E., Moncheva, S., and Konovalov, S. K.: Long-term variation of surface chlorophyll-a and primary production in the open Black Sea, Mar. Ecol.-Prog. Ser., 230, 11-28, doi:10.3354/meps230011, 2002. 